\title{
SHROOM2 wt Allele
}

National Cancer Institute

\section{Source}

National Cancer Institute. SHROOM2 wt Allele. NCI Thesaurus. Code C118552.

Human SHROOM2 wild-type allele is located in the vicinity of Xp22.3 and is approximately $163 \mathrm{~kb}$ in length. This allele, which encodes protein Shroom2, may be involved in the modulation of cell shape. Deletion of the gene may be associated with ocular albinism type 1. 